Article

\title{
Photovoltaic and Hydrogen Plant Integrated with a Gas Heat Pump for Greenhouse Heating: A Mathematical Study
}

\author{
Alexandros Sotirios Anifantis ${ }^{1, *(\mathbb{D})}$, Andrea Colantoni ${ }^{2}{ }^{(\mathbb{D})}$, Simone Pascuzzi ${ }^{1}$ \\ and Francesco Santoro ${ }^{1}$ (D) \\ 1 Department of Agricultural and Environmental Science, University of Bari Aldo Moro, 70126 Bari, Italy; \\ simone.pascuzzi@uniba.it (S.P.); francesco.santoro@uniba.it (F.S.) \\ 2 Department of Agriculture and Forestry Science, Tuscia University, 01100 Viterbo, Italy; colantoni@unitus.it \\ * Correspondence: alexandrossotirios.anifantis@uniba.it; Tel.: +39-3936-2813-86
}

Received: 11 January 2018; Accepted: 30 January 2018; Published: 1 February 2018

\begin{abstract}
Nowadays, the traditional energy sources used for greenhouse heating are fossil fuels such as LPG, diesel and natural gas. The global energy demand will continue to grow and alternative technologies need to be developed in order to improve the sustainability of crop production in protected environments. Innovative solutions are represented by renewable energy plants such as photovoltaic, wind and geothermal integrated systems, however, these technologies need to be connected to the power grid in order to store the energy produced. On agricultural land, power grids are not widespread and stand-alone renewable energy systems should be investigated especially for greenhouse applications. The aim of this research is to analyze, by means of a mathematical model, the energy efficiency of a photovoltaic $(8.2 \mathrm{~kW})$, hydrogen $(2.5 \mathrm{~kW})$ and ground source gas heat pump $(2.2 \mathrm{~kW})$ integrated in a stand-alone system used for heating an experimental greenhouse tunnel $\left(48 \mathrm{~m}^{2}\right)$ during the winter season. A yearlong energy performance analysis was conducted for three different types of greenhouse cover materials, a single layer polyethylene film, an air inflated-double layer polyethylene film, and a double acrylic or polycarbonate. The results of one year showed that the integrated system had a total energy efficiency of $14.6 \%$. Starting from the electric energy supplied by the photovoltaic array, the total efficiency of the hydrogen and ground source gas heat pump system was $112 \%$ if the coefficient of the performance of the heat pump is equal to 5 . The heating system increased the greenhouse air temperatures by $3-9{ }^{\circ} \mathrm{C}$ with respect to the external air temperatures, depending on the greenhouse cover material used.
\end{abstract}

Keywords: gas heat pump; stand-alone plant; greenhouse heating; hydrogen systems

\section{Introduction}

Greenhouses are one of the most modern expressions of recent agriculture and it is expected that they will increase in number in the future, especially in those areas with hostile climatic conditions [1]. Unfortunately, the investment required to implement a greenhouse environmental control system can be quite high and the energy costs for heating a greenhouse can reach $70 \%$ of production costs. The changes exerted by agriculture on ecosystems are characterized by the consumption of renewable and non-renewable natural resources [2-4]. In order to decrease energy costs and investigate new solutions, several research projects are taking place to focus on the micro-generation systems supplied by renewable energy sources for stand-alone applications. Furthermore, the use of renewable energy for heating structures and greenhouses is being promoted by the European Community as highlighted by the new European Directive 2010/31/CE and the Near Zero Energy Building (NZEB) concepts. In particular, in the agricultural sector, geothermal heating systems could be the best solution for 
the climate control of greenhouses [5]. Geothermal heating systems are economically advantageous and are characterized by lower environmental impact, especially in greenhouse applications $[6,7]$. Another solution is the use of solar energy systems for greenhouse heating [8]. The limiting factor of solar energy is related to the instability of solar radiation; therefore, this renewable energy source is highly variable and unpredictable. Today this problem has been resolved by storing the solar energy in chemical form such as in accumulative batteries, but these batteries typically have a limited lifetime and storage capacity. In recent years, solar energy accumulative systems in the form of chemical hydrogen energy from water electrolysis have been developed to optimize the electric current coming from the solar source and its transformation into hydrogen gas $[9,10]$. In this method, hydrogen gas is used as an energy vector for storing the solar energy.

Different processes can generate hydrogen but currently hydrogen is produced worldwide by fossil sources such as coal gasification or natural gas reforming processes. Hydrogen can also be obtained by biomass pyrolysis and by biological methods such as the dark fermentation process. This method allows the generation of hydrogen by means of micro-organisms that convert organic matter into acids and alcohols with the simultaneous liberation of hydrogen gas.

Water electrolysis is the only method which does not cause carbon dioxide emissions to be released into the atmosphere and generates "zero emissions" if compared to electricity produced by photovoltaic methods. Storage hydrogen plants can be implemented in areas not yet supplied with an electric grid, avoiding expensive investment for a single electric grid implementation [11-13]. Also, they can operate constantly under dynamic solar irradiance. Although a lot of research has been carried out on the solar photovoltaic, electrolyzer and fuel cell integrated power systems with back-up hydrogen storage systems, they are still currently under development. Some studies have investigated the integration of solar hydrogen power systems with greenhouses and have verified that these systems are a viable option for powering stand-alone greenhouses.

The storage of solar energy in the form of hydrogen can be the basis for a totally renewable energy system for generating greenhouse heating in a self-sustained way, with photovoltaic energy in combination with electrically produced hydrogen, hydrogen-storage and fuel cells connected to a ground source heat pump.

In this paper photovoltaic and hydrogen stand-alone systems integrated with a ground source gas heat pump (GSGHP) for greenhouse heating were studied. The GSGHP is a geothermal heat pump shaft connected to an internal combustion engine fed by hydrogen. Starting with the heating required by an experimental greenhouse to operate during the winter season, the research includes an evaluation of the technical aspects of the ground source gas heat pump, the hydrogen production and its storage, the photovoltaic system, and analyzes the connections and the effects among these components.

In this plant, the electrolyzer was a critical component with which water was divided into hydrogen and oxygen and the technical challenge was to make it work consistently despite the interrupted power from solar energy sources. This research was analyzed, by way of numerical simulation, the operation of alkaline water electrolyzers under both stationary and intermittent conditions, and solar photovoltaic conditions. In these studies, the main focus was on the efficiency of the ground source gas heat pump. In addition, through mathematical modeling the electrolyzer power consumption in this study considered the efficiency, and introduced the parameters that affect the behavior of each of the components. In contrast, other researchers have only studied the influence of the structure of the AC/DC converter on the thermal performance of an alkaline water electrolyzer.

Operational data was collected from the plant site under the natural conditions caused by the changeable solar radiant energy during a winter season, where the maximum value of solar radiation density was equal to $600 \mathrm{~W} \mathrm{~m}^{-2}$. In this study, the only component not implemented was the gas heat pump and its operational parameters, which were taken from the manufacturer. Instead, the analysis of the measured values allowed evaluation of the real operative achievement of the electrolyzer and its suitability for the agricultural requirements such as greenhouse heating. 
Therefore, the results of this case study may provide valuable information for further studies to better understand these devices and their associated technologies. An efficiencies analysis was conducted in order to define the total performance, as well as the power production and consumption of the integrated renewable energy system.

\section{Materials and Methods}

The experimental setup consists of a solar photovoltaic-hydrogen system powering a low enthalpy geothermal gas heat pump used for heating a greenhouse by way of hot air flow coming out of a fan-coil unit.

The study was carried out at the experimental farm of the University of Bari situated in Valenzano (Bari, Southern Italy), latitude $41^{\circ} \mathrm{N}$, where a greenhouse-integrated system composed of photovoltaic panels, an alkaline water electrolyzer, a plastic greenhouse and a geothermal heat pump were implemented. In order to understand the behavior of the heat pump, the operating values of the geothermal heat pump were measured so that the operational parameters of the GSGHP could be deduced. Then, the energy efficiency of the gas heat pump was mathematically modeled using the technical manuals provided by the manufacturer, Aisin (TOYOTA, Aichi Prefecture, Japan), whilst the rest of the system's components were analyzed using the data from the hydrogen plant implemented at the experimental farm.

The electricity coming from the solar photovoltaic source (PV) feeds the electrolyzer, the hydrogen gas produced by water electrolysis is then stored in a pressure tank, and when the photovoltaic system is inactive (during the night), the hydrogen feeds a GSGHP for greenhouse heating. The power system was designed to supply the heating load demands of the experimental greenhouse.

\subsection{The Experimental Greenhouse}

The thermal energy requirements of a greenhouse tunnel with an area of $48 \mathrm{~m}^{2}$ and a cover surface $\left(\mathrm{A}_{\mathrm{cf}}\right)$ of $106 \mathrm{~m}^{2}$ was the passive load. Tubular galvanized steel established the main structure of the greenhouse, with an arched shape roof, with glass-reinforced plastic (GRP) corrugated sheets constituting the base and the gable walls, on the East and West-facing greenhouse surfaces. Three different types of cover materials and technologies were taken into account. The first was an air inflated, double layer polyethylene film (DP), each with a thickness of $200 \mu \mathrm{m}$, with a $4 \mathrm{~cm}$ air gap kept under constant pressure by an air fan augmenting the covering. The second and the third were made of a single layer of polyethylene film (P), and a double acrylic or polycarbonate layer (DAoP). Respectively, the greenhouse thermal resistance values $(\mathrm{R})$ of the three different covering material were $0.28,0.14$ and $0.35 \mathrm{~m}^{2}{ }^{\circ} \mathrm{C} / \mathrm{W}$ (Anon, 2003).

The greenhouse heating system was made of a fan-coil unit, Carisma CRC53MV, with heating capacities of $3.59 \mathrm{~kW}$ and air flow rate of $495 \mathrm{~m}^{3} / \mathrm{h}$. The normal heat pumping unit implemented is the Model RAA-EF, Riello Company (Mississauga, ON, Canada), which used R410a as a refrigerant fluid circulating inside its circuit. Instead, the gas heat pump analyzed in the mathematical model was the Model AXGP224E1 8HP manufactured by Aisin (TOYOTA, Aichi Prefecture, Japan). According to the technical data provided by their manufacturers, the output of both heat pumps is limited to a $2.2 \mathrm{~kW}$ thermal heating capacity.

\subsection{The Integrated Power System}

The integrated power system was designed with the function of using photovoltaic production when the photovoltaic energy production and the greenhouse energy demands are not simultaneous. The system was composed of $56 \mathrm{~m}^{2}(\mathrm{APV})$ of polycrystalline photovoltaic panels $(\mathrm{PV})$, south-oriented with an elevation angle of $30^{\circ}$ in order to maximize annual energy production, that fed an electrolyzer during the daytime from 08:00 to 18:00, which produced hydrogen by water electrolysis. Furthermore, the PV modules were grouped into two parallel series, in order to achieve a nominal voltage of $360 \mathrm{~V}$ for the PV array. 
The renewable energy produced by the PV modules was converted to AC power by an inverter in order to feed the water electrolyzer. The AC power was also connected to the grid. The hydrogen was stored in a pressure tank at 30 bar, and at night, fed the ground source gas heat pump for greenhouse heating.

The alkaline barometric water electrolyzer, analyzed in this study, is a patented design, VOLTIANA ${ }^{\circledR}$. The electrolyzer, made of 33 bipolar circular cells connected in series articulate the cell stack and each one, comprising of an anode and a cathode separated by a membrane has an active area of $10^{-4} \mathrm{~m}^{2}$. The cells are fitted with frames containing channels for the distribution of the electrolyte and further channels for the collection of the electrolysis products.

According to the data from the manufacturer, the maximum rated hydrogen production is $0.5 \mathrm{Nm}^{3} \mathrm{~h}^{-1}$ at the following operational parameters: maximum pressure: $3 \mathrm{MPa}$; temperature: $80^{\circ} \mathrm{C}$; stack voltage: $62.04 \mathrm{~V}$; current intensity: $40 \mathrm{~A}$.

The electrolyte was a stationary $25-30 \mathrm{wt} \% \mathrm{KOH}$ solution. The electrolyzer was supplied by means of an electric power supply ( $3.5 \mathrm{~kW}, 230 \mathrm{VAC})$ basically consisting of an air-cooled transformer-rectifying capability, which converts the AC current into DC current. The electrolyzer is able to operate from $20 \%$ to $100 \%$ of its power rating, which is $2.5 \mathrm{~kW}$. The diagram of the plant is shown in Figure 1 and the specifications are reported in Table 1. The experiment was carried out during 2015.

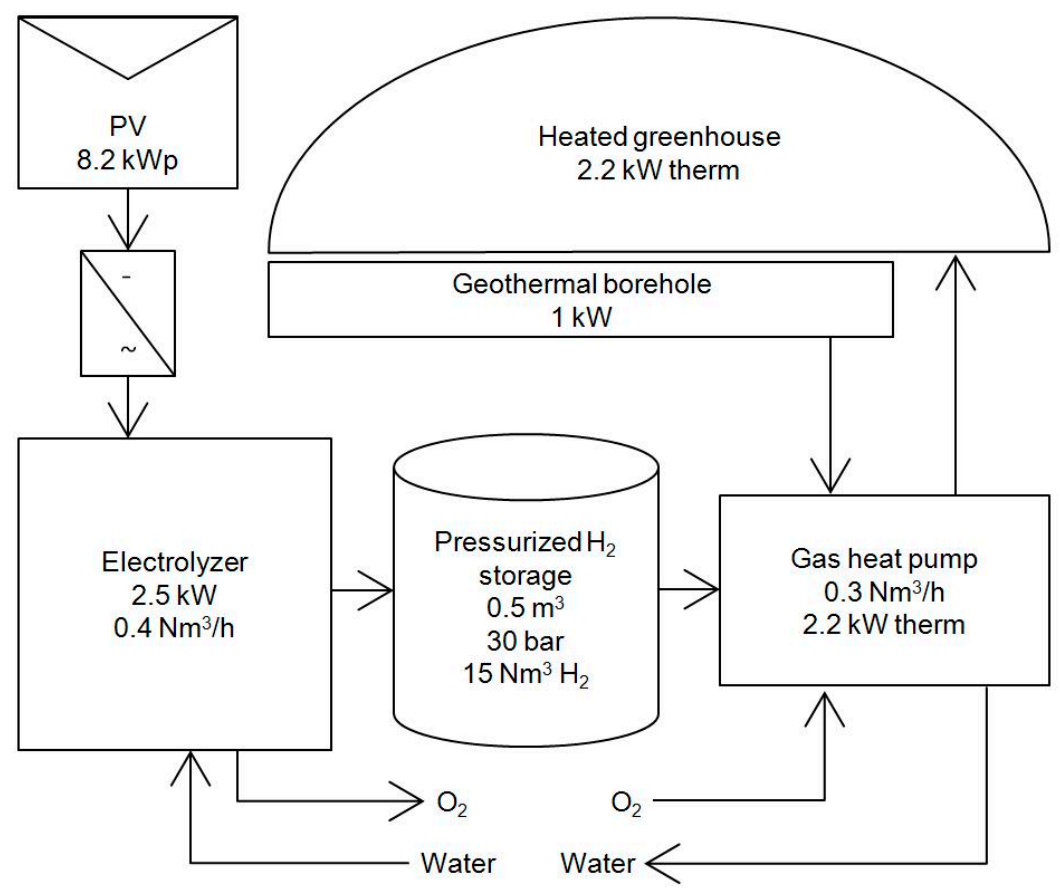

Figure 1. Photovoltaic (PV), hydrogen system and ground source gas heat pump (GSGHP) in a stand-alone application for greenhouse heating.

Hydrogen and oxygen generated in the cell stack exit by entraining to separate vessels for hydrogen and oxygen, whereas the gas phase separates out from the liquid phase, which is restored back to the cell stack. The two gases are filtered and cross final droplet separators before being delivered from the unit. Hydrogen is routed through a backpressure controller, oxygen is vented to the atmosphere.

The pressurized hydrogen ( 30 bar) produced, is stored in two steel tanks of $0.6 \mathrm{~m}^{3}$. The hybrid system is also composed of auxiliary components that together require a constant electric power $0.6 \mathrm{~kW}$ for their operation. A programmable logic controller manages all the processes and the safety of the system [9]. 
Table 1. Specifications of the stand-alone integrated plant.

\begin{tabular}{ll}
\hline Components & Specifications \\
\hline Photovoltaic array & BYD 240P6-30, 34 modules, $8.2 \mathrm{~kW}$ peak \\
Electrolyser & Monopolar alkaline electrolyzer $2.5 \mathrm{~kW}, 0.4 \mathrm{Nm}^{3} / \mathrm{h}-\mathrm{H} 2 \mathrm{Nitidor}$ S.r.l. \\
$\mathrm{H}_{2}$ storage & 30 bars, $0.5 \mathrm{~m}^{3}$ \\
Gas heat pump & Model AXGP224E1 8HP, Aisin (TOYOTA) \\
Geothermal borehole & $120 \mathrm{~m}$ vertical double U-bend ground heat exchanger \\
Fan-coil unit & Carisma CRC53MV, Heating capacities: $3.59 \mathrm{~kW}$; air flow rate $495 \mathrm{~m}^{3} / \mathrm{h}$ \\
Greenhouse & Air inflated, double layer polyethylene film greenhouse tunnel \\
\hline
\end{tabular}

\subsection{Mathematical Model}

The electrolyzer power input $\left(\mathrm{P}_{\mathrm{el}}\right)$, on a clear day, is a fraction of the instantaneous PV array power output [14]:

$$
\mathrm{P}_{\mathrm{el}}=\phi \cdot \eta_{\mathrm{vr}} \cdot \mathrm{A}_{\mathrm{PV}} \cdot \mathrm{I}_{\mathrm{T}} \cdot \eta_{\mathrm{r}}\left[1-\mathrm{B}\left(\mathrm{T}_{\mathrm{c}}-\mathrm{T}_{\mathrm{r}}\right)\right],
$$

where $\eta_{\mathrm{r}}(\sim 0.15)$ is the efficiency of the solar cell at a referenced solar radiation, $\mathrm{T}_{\mathrm{c}}\left(\sim 35^{\circ} \mathrm{C}\right)$ is the solar cell temperature, $\mathrm{T}_{\mathrm{r}}\left(\sim 25^{\circ} \mathrm{C}\right)$ is the referenced temperature of the cell and $\mathrm{B}\left(\sim 0.005^{\circ} \mathrm{C}^{-1}\right)$ is the temperature coefficient of a solar cell, $\mathrm{A}_{\mathrm{PV}}$ is the surface of the photovoltaic array, $\mathrm{I}_{\mathrm{T}}$ is the solar radiation, $\eta_{\mathrm{vr}}(\sim 0.97)$ is the DC/AC converter efficiency and $\Phi$ is the solar radiation usability.

The solar radiation usability test was necessary because the peak power of the PV array should be increased to ensure enough available power to cover the needs of the electrolyzer, considering the solar radiation curve can be used to feed the electrolyzer system for only a few hours per day.

Instead, the energy efficiency of the electrolysis reaction $\eta_{\mathrm{el}}$ is given by the expression [15]:

$$
\eta_{\mathrm{el}}=\left(\delta_{\mathrm{H} 2} \cdot \mathrm{q}_{\mathrm{el}, \mathrm{H} 2} \cdot \mathrm{LHV}_{\mathrm{H} 2}\right) / \mathrm{P}_{\mathrm{el}},
$$

where $\mathrm{LHV}_{\mathrm{H} 2}\left(119.96 \mathrm{MJ} \mathrm{kg}^{-1}\right)$ is the lower heating value of hydrogen, $\mathrm{q}_{\mathrm{el}, \mathrm{H} 2}\left(\sim 0.00011 \mathrm{Nm}^{3} \mathrm{~s}^{-1}\right)$ is the overall hydrogen production rate and $\delta_{\mathrm{H} 2}\left(\sim 0.09 \mathrm{~kg} \mathrm{Nm}^{-3}\right)$ is the hydrogen density at standard condition. The gas driven heat pump's performance was calculated by using the gas utilization efficiency (GUE) given by the manufacturer [16]:

$$
\begin{aligned}
\mathrm{GUE} & =0.64+0.32 \cdot \mathrm{COP}, \\
\mathrm{Q}_{1} & =\mathrm{GUE} \cdot \mathrm{Q}_{1 \_ \text {burner }},
\end{aligned}
$$

where the equivalent thermal power supplied by the hydrogen burner $\mathrm{Q}_{1}$ burner is given by:

$$
\mathrm{Q}_{1 \_ \text {burner }}=\delta_{\mathrm{H} 2} \cdot \mathrm{q}_{\mathrm{fc}, \mathrm{H} 2} \cdot \mathrm{LHV}_{\mathrm{H} 2} \text {, }
$$

If only $\mathrm{Q}_{1}$ and $\mathrm{Q}_{2}$ are considered, the GSGHP has the same coefficient of performance (COP) as a common GSHP:

$$
\mathrm{COP}=\mathrm{Q}_{1} /\left(\mathrm{Q}_{1}-\mathrm{Q}_{2}\right),
$$

where $Q_{1}$ is the thermal power supplied by the heat pump and $Q_{2}$ is the heat power extracted from the ground through the borehole-probe heat exchanger:

$$
\mathrm{Q}_{2}=\mathrm{q}_{\mathrm{r}} \cdot \mathrm{l}_{\mathrm{t}}
$$

where $\mathrm{q}_{\mathrm{r}}$ is the heat exchange rate and $\mathrm{l}_{\mathrm{t}}$ is the total active length of the borehole. Considering the steady state and the overnight winter conditions, the thermal power demand of the greenhouse was assessed with the equation [17]:

$$
\mathrm{Q}_{1}=\left[\mathrm{A}_{\mathrm{cf}} / \mathrm{R}\right] \cdot\left(\mathrm{f}_{\mathrm{W}}\right) \cdot\left(\mathrm{f}_{\mathrm{C}}\right) \cdot\left(\mathrm{f}_{\mathrm{S}}\right) \cdot\left(\mathrm{T}_{\mathrm{i}}-\mathrm{T}_{\mathrm{a}}\right),
$$


Assuming for each greenhouse; $1,0.9$ and 1 for the wind factor $\left(f_{W}\right)$, construction type factor $\left(f_{C}\right)$ and system factor $\left(\mathrm{f}_{\mathrm{S}}\right)$, respectively; the greenhouse thermal resistance values $(\mathrm{R})$ of the three different covering materials, DP, P and DAoP, are $0.28,0.14$ and $0.35 \mathrm{~m}^{2}{ }^{\circ} \mathrm{C} / \mathrm{W}$, respectively (Anon, 2003); then, the heat transfer coefficients $\mathrm{K}$ are $3.21,6.43$ and $2.57 \mathrm{~W} / \mathrm{m}^{2}{ }^{\circ} \mathrm{C}$, respectively.

\section{Results and Discussion}

In order to analyze the short and long-term behavior of the integrated systems, the results of the one-year analysis are shown for five representative clear, partially cloudy and cloudy winter days (18-22) in February, and for one year as monthly average values.

\subsection{Representative Five Winter Days}

For the first representative winter day, the climate conditions in Valenzano were characterized by clear skies that positively affected the performance of the photovoltaic panels and consequently, the production of the electrolyzer. The maximum solar radiation power $\left(\mathrm{I}_{\mathrm{T}}\right)$ measured during the first test day was $620 \mathrm{~W} / \mathrm{m}^{2}$, and the maximum photovoltaic electric power output ( $\left.\mathrm{P}_{\mathrm{PV}}\right)$ was $5 \mathrm{~kW}$ (Figure 2). The photovoltaic plant was oversized in order to overcome the electrolyzer power nominal input and at the same time to increase the working hours of the electrolyzer. In fact, during a typical winter day, the solar curve is small at the base but fortunately the solar radiation increases rapidly and the PV power output reaches the nominal power input of the electrolyzer quickly. For the following days, the climate conditions were characterized by partially cloudy and cloudy skies that negatively affected the performance of the photovoltaic panels, and consequently the energy production.

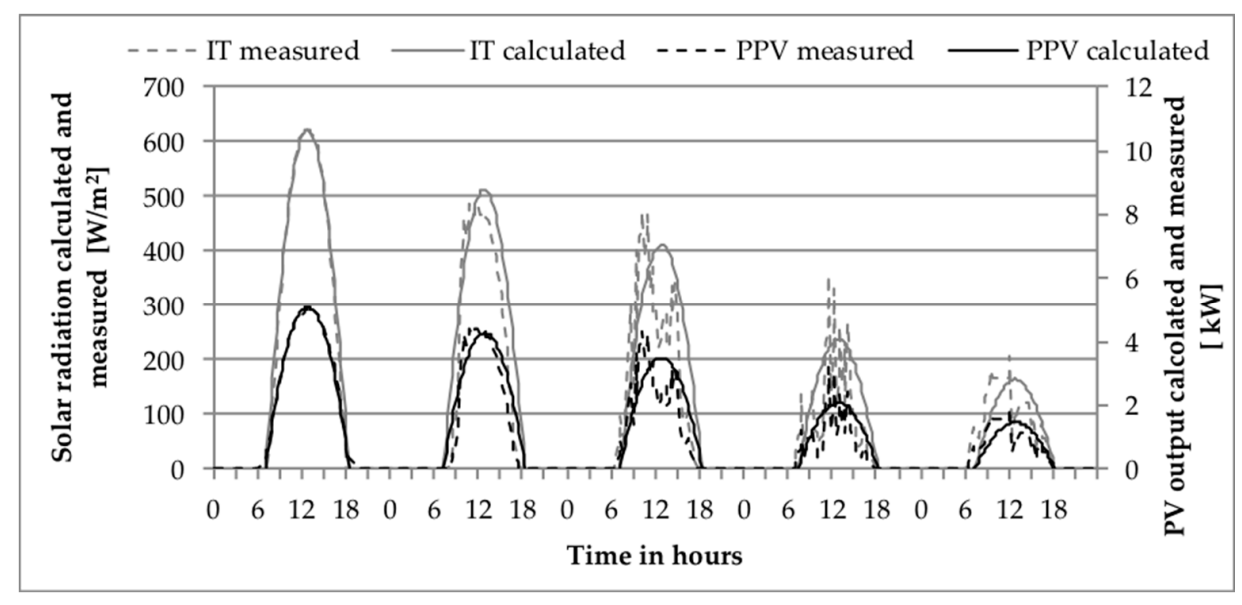

Figure 2. Solar radiation and PV electric power output calculated and measured during five representative winter days.

During the first day, the electrolyzer produced hydrogen which was ready to be stored, with a very stable hydrogen production rate, of about $0.5 \mathrm{Nm}^{3} \mathrm{~h}^{-1}$. Production of hydrogen only occurs on the condition that the electrolyzer receives a constant input of current and this only takes place if the solar curve and the photovoltaic system have an operating regime that is constant.

The electrolyzer worked in a steady state condition with small fluctuations in the hydrogen production. However, during the days characterized by a partially overcast or cloudy sky the effectiveness of the electrolyzer was intermittent with periods in which the hydrogen production was greatly reduced or discontinued. These temperamental conditions caused the electrolyzer to have low working periods. Taking into account that before each cycle/restart, the plant needs to be cleansed with nitrogen and then paused because the pressure inside the electrolyzer needs to reach the threshold value of $2.8 \mathrm{MPa}$. On the contrary, during clear sky days, the electrolyzer worked continuously, even if the hydrogen production was influenced by the solar radiation. The required measured power rose 
with the increase in the hydrogen flow rate. The efficiency of the electrolyzer was higher than $50 \%$ for hydrogen production greater than $0.4 \mathrm{Nm}^{3} \mathrm{~h}^{-1}$, and in these operational conditions the power required by the electrolyzer was close to its power rating, that is $2.5 \mathrm{~kW}$. The energy efficiency of the electrolyzer under test was evaluated by means of Equation (2). Its accuracy is affected by the experimental measurements but nevertheless, this empirical approach allows us to estimate the electrolyzer's performance, and the results showed that the energy efficiency of the electrolyzer increased by $45 \%$ (from 0.46 to 0.67 ) in the range $0.05-0.5 \mathrm{Nm}^{3} \mathrm{~h}^{-1}$ of hydrogen flow rate. The greater values of energy efficiency were linked to the highest hydrogen production even if these quantities were not directly proportional because there were continuous peaks and troughs in its efficiency as the hydrogen flow rate increased.

The geothermal heating system is not able to cover the entire heating power demand of a greenhouse; generally these renewable energy systems are coupled with a traditional diesel burner in order to cover the peaks of the energy demand during the winter. In other cases, the geothermal heating pump system is used to increase the water enthalpy before entering the boiler. In this experiment the ground source gas heat pump was used alone, without other thermal systems and the heating system started when the temperature inside the greenhouse decreased to $10{ }^{\circ} \mathrm{C}$. As shown in Figure 3, the fuel cell and the GSHP worked, at night from 18:00 to 08:00. The heat exchange rate of the geothermal borehole required $\left(\mathrm{q}_{\mathrm{r}}\right)$ for a double U-bend pipe was considered equal to $10 \mathrm{~W} \mathrm{~m}^{-1}$. During the first day, the thermal power output $\left(\mathrm{Q}_{1}\right)$ and input $\left(\mathrm{Q}_{2}\right)$ of the GSGHP was about $2 \mathrm{~kW}$ and $1 \mathrm{~kW}$, respectively. In the winter, the power output of the GSGHP was low because there was not enough hydrogen collected during daylight hours to cover the high thermal power requirements of the greenhouse. For the following days, $Q_{1}$ and $Q_{2}$ were greatly reduced because the hydrogen production was reduced.

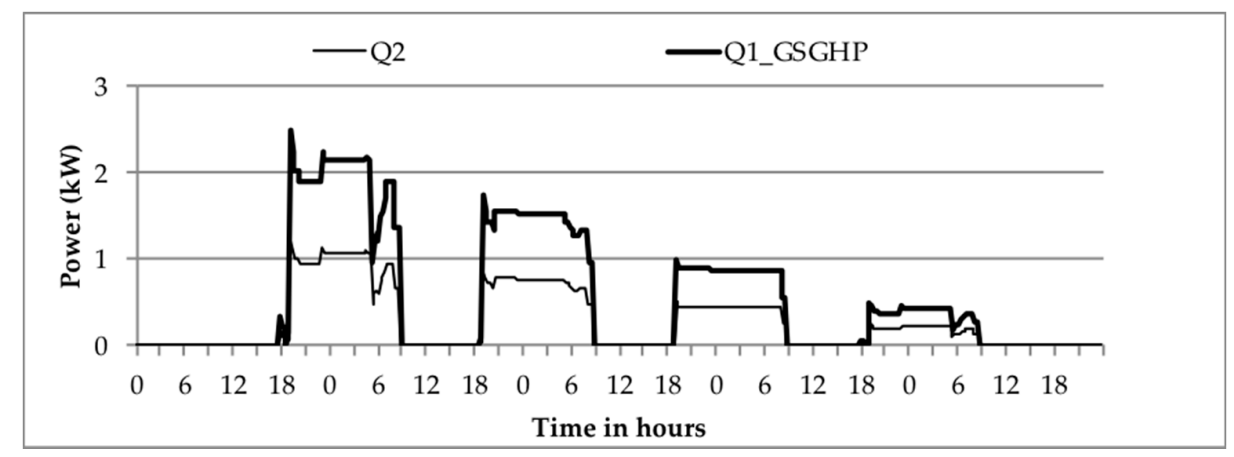

Figure 3. Heating power supplies by the ground source gas heat pump ( $\mathrm{Q}_{1}$ GSGHP$)$ and heat power extracted from the ground $\left(Q_{2}\right)$ during five representative winter days.

Unfortunately, following the clear sky of a winter day, the thermal inversion phenomena in a greenhouse at night reduces the internal greenhouse air temperature to below the external air temperature. Therefore, as shown in Figure 4, the night before the first day of testing, when the heating system was not working, the inside air temperature of the greenhouse was about $5{ }^{\circ} \mathrm{C}$ lower than the external air temperature from 01:00 to 07:00. Instead, when the heating systems were working, the difference between the indoor and outdoor greenhouse temperatures $\left(T_{i G S G H P}-T_{a}\right)$ was $8{ }^{\circ} \mathrm{C}$. These considerations led us to assess that the actual temperature increase produced by the heat pump was $13^{\circ} \mathrm{C}$. For the following days, the indoor greenhouse temperatures decreased, the solar radiation was reduced and hydrogen production was slowly reduced.

On the first day, the results show that the use of a ground source gas heat pump unit integrated with a photovoltaic stand-alone hydrogen system has a total energy efficiency of $12 \%$, starting from the sun to the GSGHP. The major limitation of the whole system was the performance of the photovoltaic system, as starting with the energy available from the PV, the system has a $96 \%$ efficiency with a heat pump COP of 4. 


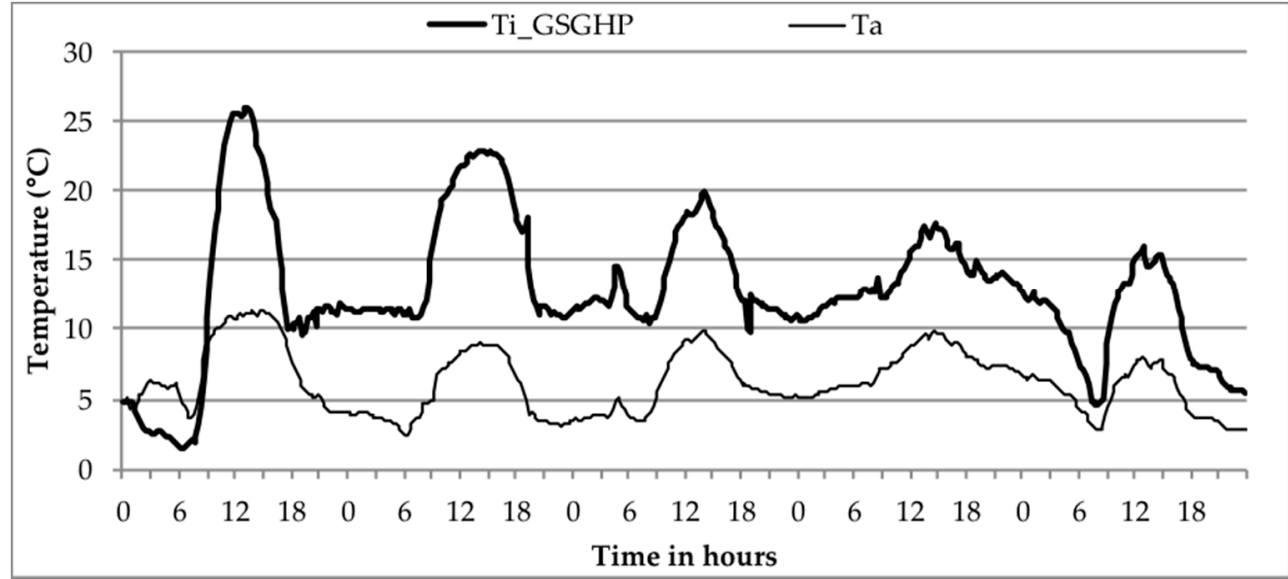

Figure 4. Internal and external greenhouse air temperature during five representative winter days.

\subsection{Monthly Average Values}

With respect to the analysis for the entire year, the monthly maximum $\left(\mathrm{I}_{\mathrm{T}_{-} \mathrm{MAX}}\right)$ and average $\left(\mathrm{I}_{\mathrm{T} \_\mathrm{AV}}\right)$ solar radiation and clearness index $\left(\mathrm{k}_{\mathrm{t} \_A V}\right)$ are reported in Figure 5. $\mathrm{I}_{\mathrm{T}_{-} \mathrm{MAX}}$ ranged from 500 to $1000 \mathrm{~W} / \mathrm{m}^{2}, \mathrm{I}_{\mathrm{T} \_A V}$ from 250 to $750 \mathrm{~W} / \mathrm{m}^{2}$ and the clearness index ranged from 0.23 to 0.58 . In the winter season, the monthly average clearness index was low (from 0.23 to 0.35 ) because cloud and rain dominated the weather in the winter period in 2015, thus, the monthly average efficiency of the plant can be compared to the efficiency of a cloudy day. The monthly average values coincide with the daily values if the clearness index is the same, and from the different values of the monthly average values it is also possible to understand the daily performance of the system for cloudy (0.20), partly cloudy (0.40) and clear (0.60) days. In the summer, if there is a demand for cooling and there is not enough natural ventilation, dynamic ventilation of the greenhouse is necessary and electricity from PV panels can operate the fans $[18,19]$ or the cycle of the GSGHP can be inverted.

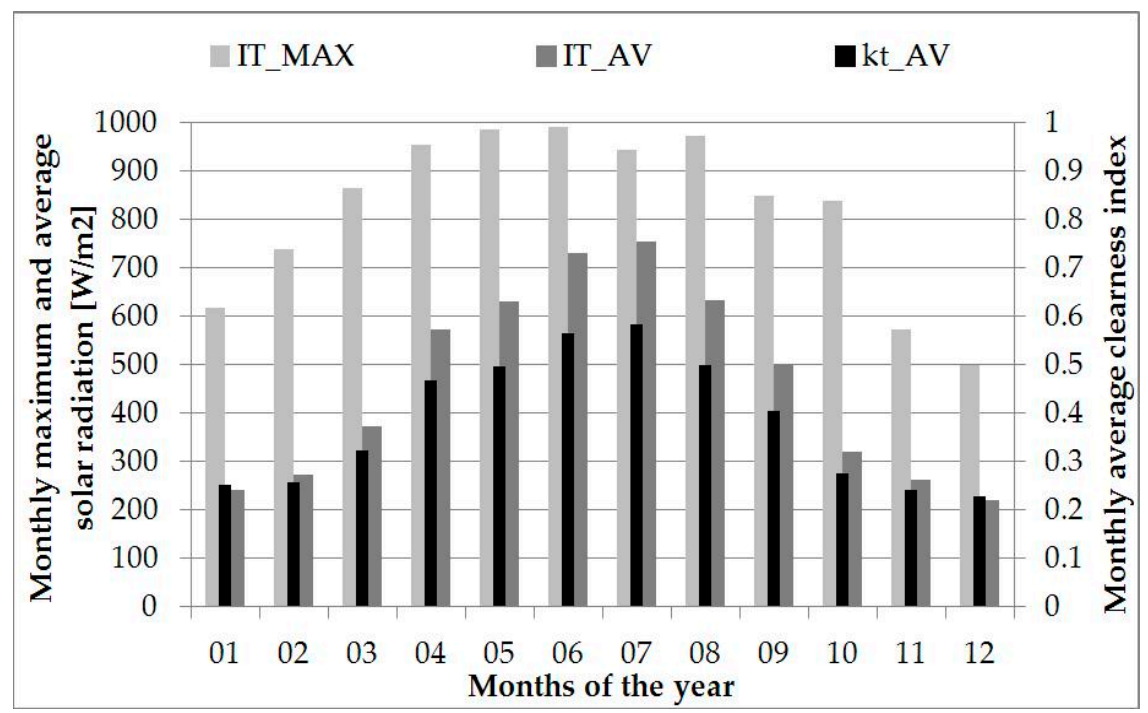

Figure 5. Monthly maximum ( $\left.\mathrm{I}_{\mathrm{T} \_\mathrm{MAX}}\right)$ and average $\left(\mathrm{I}_{\mathrm{T} \_\mathrm{AV}}\right)$ solar radiation and clearness index $\left(\mathrm{k}_{\mathrm{t}}\right)$ in 2015.

The monthly average performances of the electrolyzer is highly dependent on the $\mathrm{I}_{\mathrm{T}} \mathrm{AV}$ and $\mathrm{k}_{\mathrm{t}}$. During 2015, the monthly average photovoltaic electric power output ( $\mathrm{P}_{\mathrm{PV} \_A V}$ ) ranged from 1.2 to $5 \mathrm{~kW}$ (Figure 6) and consequently, the monthly average electrolyzer mass flow output ( $\mathrm{q}_{\mathrm{el}, \mathrm{H} 2 \_\mathrm{AV}}$ ) ranged 
from 150 to $420 \mathrm{NL} / \mathrm{h}$. In the winter period, the gap between the $\mathrm{P}_{\mathrm{PV}_{-} A V}$ and the monthly average electrolyzer power input ( $\mathrm{P}_{\mathrm{EL} \_\mathrm{AV}}$ ) was low in the summer. The use of solar energy for the purpose of electrolysis was higher in the winter than the summer. However, in the winter period, $\mathrm{q}_{\mathrm{el}, \mathrm{H} 2 \_\mathrm{AV}}$ was low due to the low values of the $\mathrm{k}_{\_} \mathrm{AV}$.

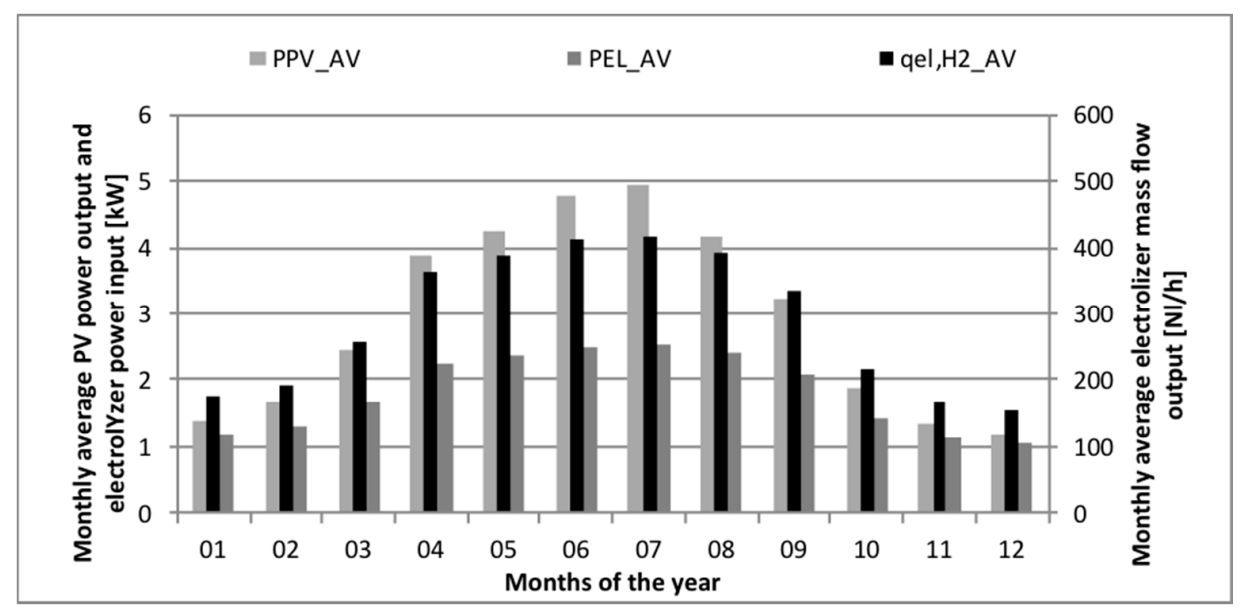

Figure 6. Monthly average photovoltaic power output $\left(\mathrm{P}_{\mathrm{PV} \_A V}\right)$, electrolyzer power input $\left(\mathrm{P}_{\mathrm{EL} \_\mathrm{AV}}\right)$ and electrolyzer mass flow output (qel,H2_AV) in 2015.

During daylight hours, at Valenzano's latitude, the greenhouse heating system was turned off because the greenhouse effect was enough to raise the air temperature inside the greenhouse. The average values of the GSGHP, shown in Figure 6, were calculated at night from 18:00 to 8:00, when the geothermal heating system was in use.

In the coolest winter months, the daily hydrogen produced was not enough to satisfy the mass flow demand of the GSGHP. The monthly average heating power supplied by the ground source gas heat pump $\left(\mathrm{Q}_{1}\right.$ GSGHP_AV $)$ increased to double from January to April due to the increase of the $\mathrm{I}_{\mathrm{T}} \mathrm{AV}$, $\mathrm{k}_{\mathrm{t}}$ and the number of light hours per day.

The average monthly thermal power output $\left(\mathrm{Q}_{1} \_\mathrm{AV}\right)$ and input $\left(\mathrm{Q}_{2} \mathrm{AV}\right)$ of the GSGHP ranged from 0.8 to $2 \mathrm{~kW}$ and from 0.4 to $1 \mathrm{~kW}$, respectively (Figure 7). The average yearly value of the gas utilization efficiency (GUE) of the GSGHP was $224 \%$, considering a COP of 5.

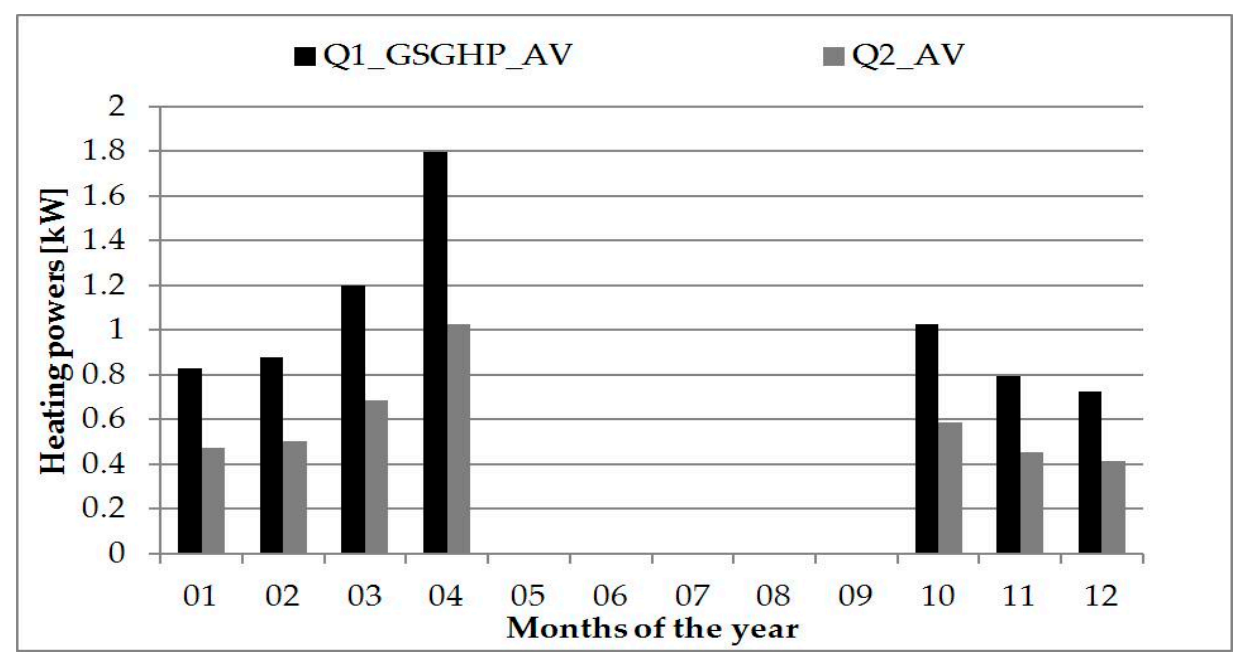

Figure 7. Monthly average heating power supplied by the ground source gas heat pump ( $\mathrm{Q}_{1}$ GSGHP_AV $)$ and heat power extracted from the ground $\left(\mathrm{Q}_{2} \mathrm{AV}\right)$ in 2015. 


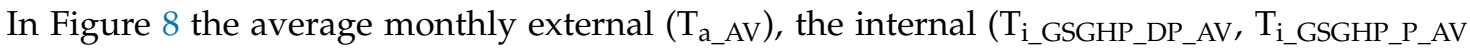
and $\mathrm{T}_{\mathrm{i}_{-} G S G H P \text { DAAoP_AV }}$ ) greenhouse air temperatures of the three different cover materials (DP, $\mathrm{P}$ and DAoP) are shown. As before, the average monthly values were calculated when the geothermal heating system was working overnight, from 18:00 to 8:00. As shown the difference between the $\mathrm{T}_{\mathrm{i}_{-} G S G H P}$ DAoP_AV and the $\mathrm{T}_{\mathrm{a}_{-} A V}$ ranged from 5 (in January) to $9{ }^{\circ} \mathrm{C}$ (in April). Instead, for the DP cover material the difference ranged from 4.5 (in January) to $7.5^{\circ} \mathrm{C}$ (in April) and the P cover material ranged from 3 (in January) to $5^{\circ} \mathrm{C}$ (in April). The heating contributions of the GSGHP for P cover material were very low and the temperatures reached inside the greenhouse did not justify the investment. For this reason, this system is only sustainable for greenhouses with a cover film with high thermal resistance values.

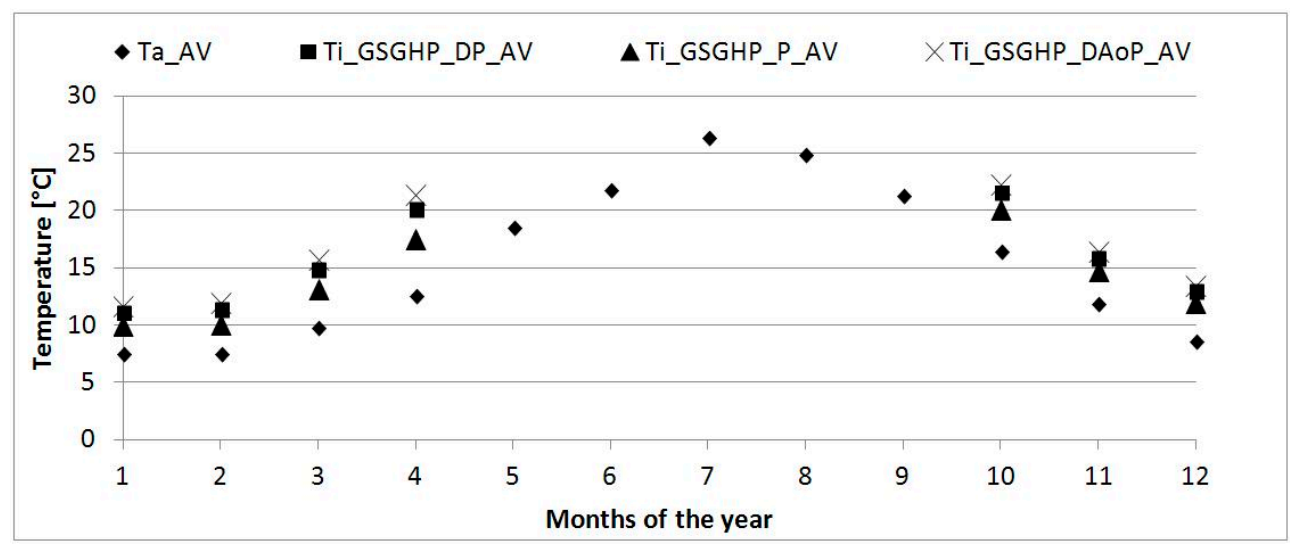

Figure 8. Average monthly internal and external greenhouse air temperatures for three different cover materials in 2015.

\section{Conclusions}

The paper analyzed the overall performance efficiency of a ground source gas heat pump integrated with a stand-alone renewable energy plant for greenhouse heating.

The results obtained in these trials and the mathematical model implemented gave us information about the performance and efficiency of the alkaline barometric water electrolyzer (VOLTIANA ${ }^{\circledR}$ ) and the geothermal source gas hat pump (Aisin-TOYOTA). The trials also gave us an insight into the usage of a greenhouse-integrated heating system comprised of photovoltaic panels, an alkaline barometric water electrolyzer, hydrogen storage and geothermal source gas heat pump, even if further tests are required to better assess the GSGHP's performance. The electrolyzer worked non-stop during the days characterized by clear skies, but the electrical power supplied by the PV modules was greatly affected by the very unstable solar radiation typical of partially cloudy days. In these cases, the electrolyzer's overall operation was sometimes disjointed for many hours due to intemperate weather conditions in which the hydrogen production ceased. The required stack power rose with the increase in hydrogen flow rate, but the efficiency was only higher than $50 \%$ when the power required by the electrolyzer was close to its power rating $(2.5 \mathrm{~kW})$, and the corresponding hydrogen production greater than $0.4 \mathrm{Nm}^{3} \mathrm{~h}^{-1}$. The gas utilization efficiency of the ground source gas heat pump was strictly linked to the coefficient of performance of the heat pump, the ground temperature and the heat exchange rate of the geothermal borehole. Considering a COP of 5, the average yearly value of the GUE of the GSGHP was $224 \%$. Thanks to the GUE, it was possible to double the efficiency of the systems.

In comparison to the COP of a traditional geothermal heat pump, the GUE seems low and not competitive, but if we consider that, in this case, a fuel cell was not used to convert hydrogen into electricity, it follows that the global efficiency of the proposed system was greater than a system composed of a traditional heat pump that works in the same conditions (COP $=5)$ and a fuel cell $(\eta \sim 40 \%)$ [5] instead of a GSGHP (GUE $=224 \%)$. 
Throughout the trial period, due to the different values of the average monthly solar radiation and clearness index, it was possible to investigate the behavior of the plant in different weather conditions. In fact, both the solar radiation and clearness index were highly connected to the efficiency of the plant. In winter, the clearness index was high; if the solar radiation peak and the day light period were low, the plant utilization factor was low.

Finally, the energy efficiency of the plant is strongly affected by the electrolyzer and the gas heat pump management, the $\mathrm{I}_{\mathrm{T}_{-} \mathrm{AV}}, \mathrm{k}_{\mathrm{t}}$ and the number of light hours per day. Considering an energy efficiency for the photovoltaic panels of $13 \%$, an electrolyzer energy efficiency equal to $50 \%$, and a ground source gas heat pump GUE of $224 \%$, the overall system efficiency is $14.6 \%$. The heating system increases the greenhouse temperature by $3-9^{\circ} \mathrm{C}$ in respect to the external air temperatures, depending on the greenhouse cover material used in the winter period.

The data analysis for the experiment indicated some key areas for further research. For example, the size of the greenhouse was very small and needs to be increased in order to assess large-scale energy performance. An economic study is necessary to evaluate the sustainability of the investment. An alternative system to hydrogen such as a biogas/bio-methane plant combined with the GSGHP could also be investigated. In this case the use of the system should also be assessed in the summer months where the demand for thermal energy is zero and further analyses should be conducted. Finally, future developments should focus on the use of solar thermal systems to increase the enthalpy of the fluid entering the GSGHP, and the improvement of the GUE.

Acknowledgments: Funding source: Fondo di Sviluppo e Coesione 2007-2013-APQ Ricerca Regione Puglia "Programma regionale a sostegno della specializzazione intelligente e della sostenibilità sociale ed ambientale-FutureInResearch". We thank Costantinos Anifantis, Franco Ferrulli, Flavio Castellano, Domenico Tarantino and Davide Sfregola for their technical assistance.

Author Contributions: Alexandros Sotirios Anifantis and Simone Pascuzzi conceived and designed the experiments; Andrea Colantoni performed the experiments; Alexandros Sotirios Anifantis and Francesco Santoro analyzed the data; Alexandros Sotirios Anifantis wrote the paper.

Conflicts of Interest: The authors declare no conflict of interest.

\section{References}

1. Blanco, I.; Anifantis, A.S.; Pascuzzi, S.; Scarascia Mugnozza, G. Hydrogen and renewable energy sources integrated system for greenhouse heating. J. Agric. Eng. 2013, 44, 226-230. [CrossRef]

2. Russo, G.; Verdiani, G.; Anifantis, A.S. Re-use of agricultural biomass for nurseries using proximity composting. Contemp. Eng. Sci. 2016, 9, 1151-1182. [CrossRef]

3. Pascuzzi, S. A multibody approach applied to the study of driver injures due to a narrow-track wheeled tractor rollover. J. Agric. Eng. 2015, 46, 105-114.

4. Manetto, G.; Cerruto, E.; Pascuzzi, S.; Santoro, F. Improvements in citrus packing lines to reduce the mechanical damage to fruit. Chem. Eng. Trans. 2017, 58, 391-396.

5. Anifantis, A.S.; Colantoni, A.; Pascuzzi, S. Thermal energy assessment of a small scale photovoltaic, hydrogen and geothermal stand-alone system for greenhouse heating. Renew. Energy 2017, 103, 115-127. [CrossRef]

6. Anifantis, A.S.; Pascuzzi, S.; Scarascia-Mugnozza, G. Geothermal source heat pump performance for a greenhouse heating system: An experimental study. J. Agric. Eng. 2016, 47, 164-170. [CrossRef]

7. Pascuzzi, S.; Santoro, F. Analysis of the almond harvesting and hulling mechanization process: A case study. Agriculture 2017, 7, 100. [CrossRef]

8. Hassanien, R.H.E.; Li, M.; Dong Lin, W. Advanced applications of solar energy in agricultural greenhouses. Renew. Sustain. Energy Rev. 2016, 54, 989-1001. [CrossRef]

9. Pascuzzi, S.; Anifantis, A.S.; Blanco, I.; Scarascia-Mugnozza, G. Electrolyzer performance analysis of an integrated hydrogen power system for greenhouse heating a case study. Sustainability 2016, 8, 629. [CrossRef]

10. Pascuzzi, S.; Santoro, F. Analysis of Possible Noise Reduction Arrangements inside Olive Oil Mills: A Case Study. Agriculture 2017, 7, 88. [CrossRef] 
11. Pascuzzi, S.; Blanco, I.; Anifantis, A.S.; Scarascia-Mugnozza, G. Hazards assessment and technical actions due to the production of pressured hydrogen within a pilot photovoltaic-electrolyser-fuel cell power system for agricultural equipment. J. Agric. Eng. 2016, 47, 88-93. [CrossRef]

12. Pascuzzi, S.; Santoro, F. Evaluation of farmers' OSH hazard in operation nearby mobile telephone radio base stations. In Proceedings of the 16th International Scientific Conference "Engineering for Rural Development", Jelgava, Latvia, 24-26 May 2017; Volume 16, pp. 748-755.

13. Pascuzzi, S.; Santoro, F. Exposure of farm workers to electromagnetic radiation from cellular network radio base stations situated on rural agricultural land. Int. J. Occup. Saf. Ergon. 2015, 21, 351-358. [CrossRef] [PubMed]

14. Anifantis, A.S. Performance assessment of photovoltaic, ground source heat pump and hydrogen heat generator in a stand-alone systems for greenhouse heating. Chem. Eng. Trans. 2017, 58, 511-516.

15. Calderóna, M.; Calderóna, A.J.; Ramirob, A.; Gonzálezb, J.F.; Gonzáleza, I. Evaluation of a hybrid photovoltaic-wind system with hydrogen storage performance using exergy analysis. Int. J. Hydrogen Energy 2011, 36, 5751-5762. [CrossRef]

16. TecnoCasa Climatizzazione Sole European Distributor AISIN, Gas Heat Pump (GHP)/Microcogenerator (MCHP). Available online: www.tecno-casa.com (accessed on 15 September 2017).

17. Ozgener, O.; Hepbasli, A. Performance analysis of a solar-assisted ground-source heat pump system for greenhouse heating: An experimental study. Build. Environ. 2005, 40, 1040-1050. [CrossRef]

18. Trypanagnostopoulos, G.; Kavga, A.; Souliotis, M.; Tripanagnostopoulos, Y. Greenhouse performance results for roof installed photovoltaics. Renew. Energy 2017, 111, 724-731. [CrossRef]

19. Kavga, A.; Karanastasi, E.; Konstas, I.; Panidis, T. Performance of an infrared heating system in a production greenhouse. IFAC Proc. Vol. 2013, 46, 235-240. [CrossRef]

(C) 2018 by the authors. Licensee MDPI, Basel, Switzerland. This article is an open access article distributed under the terms and conditions of the Creative Commons Attribution (CC BY) license (http:/ / creativecommons.org/licenses/by/4.0/). 